NBER WORKING PAPER SERIES

OLDER PEOPLES' WILLINGNESS TO DELAY SOCIAL SECURITY CLAIMING

\author{
Raimond Maurer \\ Olivia S. Mitchell \\ Working Paper 22942 \\ http://www.nber.org/papers/w22942 \\ NATIONAL BUREAU OF ECONOMIC RESEARCH \\ 1050 Massachusetts Avenue \\ Cambridge, MA 02138 \\ December 2016
}

The research reported herein was performed pursuant to a grant from the U.S. Social Security Administration (SSA) funded as part of the Michigan Retirement Research Center. Additional research support was provided by the Deutsche Forschungsgemeinschaft (DFG), the German Investment and Asset Management Association (BVI), the Pension Research Council/Boettner Center at The Wharton School of the University of Pennsylvania, and the Metzler Exchange Professor program. We also acknowledge support from the Research Center SAFE, funded by the State of Hessen initiative for research excellence, LOEWE. We are grateful for expert programming assistant from Yong $\mathrm{Yu}$, and for help with the survey module from the HRS team, particularly Mary Beth Ofstedal. We also benefited from pilot tests conducted at the Wharton Behavioral Labs. Opinions and conclusions expressed herein are solely those of the authors and do not represent the opinions or policy of SSA, any agency of the Federal Government, or any other institution with which the authors are affiliated. The views expressed herein are those of the authors and do not necessarily reflect the views of the National Bureau of Economic Research.

At least one co-author has disclosed a financial relationship of potential relevance for this research. Further information is available online at http://www.nber.org/papers/w22942.ack

NBER working papers are circulated for discussion and comment purposes. They have not been peer-reviewed or been subject to the review by the NBER Board of Directors that accompanies official NBER publications.

(C) 2016 by Raimond Maurer and Olivia S. Mitchell. All rights reserved. Short sections of text, not to exceed two paragraphs, may be quoted without explicit permission provided that full credit, including $\odot$ notice, is given to the source. 
Older Peoples’ Willingness to Delay Social Security Claiming

Raimond Maurer and Olivia S. Mitchell

NBER Working Paper No. 22942

December 2016

JEL No. D03,D91,G11,H55

\begin{abstract}
We have designed and fielded an experimental module in the 2014 HRS which seeks to measure older persons' willingness to voluntarily defer claiming of Social Security benefits. In addition, we evaluate the stated willingness of older individuals to work longer, depending on the Social Security incentives offered to delay claiming their benefits. Our project extends previous work by analyzing the results from our HRS module and comparing findings from other data sources which included very much smaller samples of older persons. We show that half of the respondents would delay claiming if no work requirement were in place under the status quo, and only slightly fewer, $46 \%$, with a work requirement. We also asked respondents how large a lump sum they would need with or without a work requirement. In the former case, the average amount needed to induce delayed claiming was about $\$ 60,400$, while when part-time work was required, the average was $\$ 66,700$. This implies a low utility value of leisure foregone of only $\$ 6,300$, or under $20 \%$ of average household income.
\end{abstract}

\author{
Raimond Maurer \\ Goethe University Frankfurt \\ Finance Department \\ Theodor-W. Adorno Platz 3 \\ 60323 Frankfurt am Main \\ Germany \\ maurer@finance.uni-frankfurt.de \\ Olivia S. Mitchell \\ University of Pennsylvania \\ The Wharton School \\ 3620 Locust Walk, St 3000 SH-DH \\ Philadelphia, PA 19104-6302 \\ and NBER \\ mitchelo@wharton.upenn.edu
}




\title{
Older Peoples’ Willingness to Delay Social Security Claiming
}

\author{
Raimond Maurer and Olivia S. Mitchell
}

When to claim Social Security benefits is a momentous financial decision confronting 10,000 Baby Boomers retiring per day until the year 2029 (Pew 2010). At present, these benefits are provided as a lifelong benefit stream beginning as early as age 62, or they can be delayed to later ages up to age 70 . That is, claiming early reduces one's benefit amounts, whereas deferring claiming entitles the individual to a lifetime benefit $8 \%$ higher per year that claiming is delayed (Maurer et al. 2016, Shoven and Slavov 2012, 2014). Under current rules, on average the system neither makes nor loses money for those who delay, as the benefit increment earned by waiting is more or less actuarially fair.

Yet contrary to basic insurance principles, most Americans claim benefits and stop working around age 62. One explanation for this behavior is that their advisers focus on the so-called "breakeven” approach to claiming: that is, they encourage workers to claim early to avoid potentially "forfeiting" their deferred benefits should they die too soon (Brown et al. 2016a). A second explanation for early claiming is that many people underweight the economic value of lifetime benefit streams (Brown et al. 2016b). This latter rationale motivates the current study, which explores whether making the benefit increment due to delayed claiming payable as a lump sum instead of a benefit stream, could serve as an incentive to drive later claiming and longer worklives. ${ }^{1}$

\footnotetext{
${ }^{1}$ Other incentives to encourage delayed claiming in the US context have been analyzed by Laitner and Silverman (2012); a recent analysis of delayed claiming in Norway is provided by Hernæs (2016).
} 
In what follows, we describe an experimental module we designed and fielded in the 2014 Health and Retirement Study (HRS) to measure older persons' willingness to voluntarily defer claiming of Social Security benefits, and potentially to work longer, as a function of incentives to delay claiming their benefits. We focus on a nationally representative sample of people age 50-70, for whom claiming decisions are of the utmost financial importance, and we investigate whether and which individuals might be willing to delay claiming Social Security benefits in exchange for different compensation options.

We find that many older Americans would be willing to delay claiming their Social Security benefits if they were offered an actuarially fair lump sum to do so. Overall, half (49.9\%) of the respondents say they would delay claiming if no work requirement were in place under the status quo, and only slightly fewer (46\%) with a work requirement. When offered a lump sum of $\$ 60,000$ to delay claiming, an amount that is approximately actuarially fair, willingness to delay rises to $70.3 \%$ without a work requirement, and $55.5 \%$ with a work condition. We also asked respondents to tell us how large a lump sum they would need with and without a work requirement. When no work is required, the average amount needed to induce delayed claiming is about $\$ 60,400$, while when part-time work is required, the average was $\$ 66,700$. This implies a low utility value of leisure foregone of only $\$ 6,300$, or under $20 \%$ of average household income. Our findings will interest policymakers seeking to encourage longer worklives by enhancing delayed claiming incentives.

\section{Prior Literature}

There are several good economic reasons that people might delay claiming their Social Security benefits rather than taking them as early as possible, at age 62. One reason to defer 
claiming is that an $8 \%$ increase in benefits per year of delay is likely to be far more than most people can earn on their own (Coile et al. 2002). A second reason to delay claiming is that, even though the benefit increase is roughly actuarially fair, risk-averse individuals will value the higher deferred benefit as it provides insurance protection against outliving their retirement savings. ${ }^{2}$ And yet another reason - particularly relevant to those in better-than-average health - is that this gives them access to higher payments for their anticipated longer-than-average lifetimes. ${ }^{3}$

In our prior theoretical work, we explored whether a reform that gave people an actuarially fair lump sum as a payment for delayed retirement rather than as an addition to their lifetime Social Security benefits might induce them to work longer on a voluntary basis (Chai et al. 2013). We modeled the factors influencing how economic actors would trade off a benefit stream for a lump sum, and we examined the consequences of such tradeoffs for work, retirement, and life-cycle wellbeing. Our findings suggested that, given the chance to receive a delayed retirement credit as a lump sum payment, workers would delay retirement ages by 1-2 years, with little or no decline in welfare. Results were robust to the inclusion of bequest motives. Thus, from a theoretical vantage point, providing a lump sum does not simply result in wealth transfers to the next generation, consistent with the rationale for Social Security as a national social insurance scheme intended to support consumption for the elderly.

In a previous empirical test of this idea, we used the American Life Panel to investigate related questions in a survey setting (Maurer et al. 2016). There we showed that people would voluntarily claim about six months later when a lump sum was paid for claiming beyond the Early Retirement Age. Overall, individuals stated that they would work about one-third to one-half of

\footnotetext{
${ }^{2}$ Gustman and Steinmeir (2016) show that those who are more confident about the future of Social Security will delay claiming.

${ }^{3}$ Deferring claiming can also boost both spouse and spousal survivor benefits; see Gustman and Steinmeier (2015) and Huebner et al. (2015).
} 
the additional months, and those who said they preferred to claim young under the status quo were also most responsive to the lump sum offer. A drawback of that study is that it included respondents of all ages (18-70) to generate sufficient sample sizes for analysis, even though people age 50+ would be more likely to take the question seriously and evaluate its importance to their own lives. Accordingly, in what follows, we use a specially-designed module we developed for the Health and Retirement Study (HRS) to concentrate on older individuals age 51-70, the group for whom benefit claiming decisions are most relevant.

\section{Methods}

Our approach examines empirically whether people might be willing to delay claiming Social Security benefits in exchange for alternative compensation options. To this end, we devised and implemented a module on a subset of respondents age 70 or under in the 2014 HRS containing two sets of questions. ${ }^{4}$ The first set examined whether HRS respondents would be willing to receive their delayed retirement benefit from Social Security as a lump sum instead of a lifetime benefit stream, without their needing to work longer. In a second setting, we also explored leisure preferences by asking whether respondents who had to work longer would exchange delayed benefits for a lump sum. In both settings, the compensation for delay (and work, in the second case) was framed either as a lump sum or a lifelong payment stream.

The No Work Condition: To introduce the concepts we sought to measure, we first showed each respondent a scenario as to whether he would prefer to claim $\$ 1,000$ per month in monthly benefits at age 62 , or wait to age 66 when he could claim $\$ 1,330$ in monthly payments for life. This

\footnotetext{
${ }^{4}$ The complete questionnaire appears in the Online Appendix.
} 
presentation stipulated that the individual had sufficient private saving so he would not need to work for any additional years:

For the sake of these questions, assume that you are currently age 62, and you are single. You are thinking about when to claim your Social Security benefit. If you claim it at age 62, you will receive $\$ 1,000$ per month for life.

Now imagine you have a choice: either you can receive that $\$ 1,000$ monthly benefit from age 62 for life, or you can delay receiving the benefit until age 66. If you delay, assume that you have enough savings to live on without working from age 62 to age 66. Assume that, on average, the government will neither lose nor make money as a result.

In exchange for delaying your Social Security benefit until age 66, you will receive a monthly benefit of \$1,330 dollars per month from age 66 for life. Would you be willing to delay receiving your benefit until age 66 ? $\{$ Yes/No/DK/ RF $\}$

Since the size of the larger benefit payable for delay is consistent with the status quo Social Security rules, we classified a respondent as “willing to delay claiming under the Status Quo” if he responded “Yes” (WillingtoWaitSQ). Otherwise, his response was coded as “No, Don’t Know”, or "Refuse."

Next, we asked the respondent to indicate whether he would be willing to delay claiming for the actuarially equivalent value of $\$ 1,000$ taken at age 62 , or $\$ 1,000$ plus a lump sum of $\$ 60,000$ if claimed at age $66^{5}$ :

Now suppose that in exchange for delaying your Social Security benefit until age 66 , you will then receive a monthly benefit of $\$ 1,000$ per month from age 66 for life, plus a lump sum of $\$ 60,000$ paid at age 66 . Would you be willing to delay receiving your benefit to age 66 ? $\{\mathrm{Yes} / \mathrm{No} / \mathrm{DK} / \mathrm{RF}\}$

Someone saying "Yes" was routed to a subsequent question where he was asked to specify the smallest lump sum he would take, payable at age 66 , paired with the same $\$ 1,000$ monthly benefit. ${ }^{6}$

\footnotetext{
${ }^{5}$ Assuming a 2.9\% interest rate (used by the Social Security Trust Fund in its intermediate cost scenario), a unisex table based on mortality probabilities used in the Social Security's Trustees Report (SSA 2013), and a full retirement age of 66 , the value of $\$ 60,000$ is basically actuarially fair. See Maurer et al. (2016).

${ }^{6}$ Unfolding brackets in this and the next question were offered to people that did not give an amount; see the Online Appendix.
} 
Someone saying "No" was routed to a question asking what he would need as a larger lump sum to delay benefits to age 66 , again paired with the $\$ 1,000$ monthly amount.

The Work Condition: The second presentation we showed respondents stipulated that the individual had to work at least half time to receive the higher deferred benefit:

Again, assume you are currently age 62, and you are single. And again you have a similar choice: either you can receive that $\$ 1,000$ monthly benefit for life from Social Security from age 62, or you can delay receiving the benefit until age 66. If you delay, again assume that you have enough savings to live on without working from age 62 to age 66, but you must work at least half time in all four years to get the increased benefit. Like before, assume that, on average, the government will neither lose nor make money as a result.

In exchange for delaying your Social Security benefit and working four additional years until age 66, you will receive a monthly benefit of $\$ 1,330$ per month from age 66 for life. Would you be willing to work longer and delay receiving the benefits to age 66? \{Yes/No/DK/ RF $\}$

Instead, in exchange for delaying your Social Security benefit and working four additional years until age 66 , you will receive a monthly benefit of $\$ 1,000$ per month from age 66 for life, plus a lump sum of $\$ 60,000$ paid at age 66 . Would you be willing to work longer and delay receiving the benefits to age 66 ? $\{\mathrm{Yes} / \mathrm{No} / \mathrm{DK} / \mathrm{RF}\}$

Someone responding "Yes" to the last question with the work requirement was again routed to a subsequent question where he was asked to specify the smallest lump sum he would take, payable at age 66, paired with the same $\$ 1,000$ monthly benefit." Someone saying "No" was routed to a question asking what he would need to get as a larger lump sum to delay benefits to age 66, again paired with the work requirement and the $\$ 1,000$ monthly amount.

Accordingly, the goals of this experiment were to measure the respondent's willingness to trade a decrease in his annuity benefit stream for a delayed lump sum (i) if no extra work were required in the interim; and (ii) if at least half-time work were required. In what follows, we

\footnotetext{
${ }^{7}$ Unfolding brackets in this and the next question were offered to people that did not give an amount; see the Online Appendix.
} 
describe our results and examine how respondents answered these questions, controlling on important social and demographic factors including age, education, marital status, work history, risk aversion, and anticipated longevity, with the latter variables taken from the Core HRS.

\section{Results: Descriptive Statistics}

In Figure 1 we report the frequencies of dollar amounts respondents indicate they would demand in order to delay claiming benefits. The two lighter bars in each category indicate how much respondents would need to delay in the no work condition, while the two darker bars indicate the response when half-time work is required. The modal respondent indicated that his "price to delay” claiming from age 62 to age 66 was $\$ 60-80,000$, whether or not work was required. Nevertheless, a large share of those surveyed indicated that they would accept smaller amounts as lump sums. For instance, 34\% would take less than \$60,000 in the no work condition, and 30\% would do so in the work condition. This is, as noted above, less than the actuarially fair amount. Very few respondents would demand over $\$ 100,000$ to delay claiming: only 3\% in the no work condition, and 5\% in the work condition. The dollar value of the lump sum required to incentivize people to delay claiming in the no-work condition averaged $\$ 53,711$ (with a standard deviation of $\$ 29,000$ ), while the amount was $\$ 61,406$ (with a larger standard deviation of $\$ 53,417$ ) when parttime work was required.

Figure 1 here

Table 1 reports the frequency of respondents indicating they would delay claiming under the Lump Sum versus the Status Quo. The statistics report respondents' willingness to delay overall, as well as by sex, age bracket, educational category, race/ethnicity, and self-reported health (excellent/very good/good versus fair/poor. Our findings show that, overall, close to half - 
$49.9 \%$ - of the respondents agreed that they would delay claiming if no work requirement were in place under the status quo, and only slightly fewer, 46\%, with a work requirement. Many people indicated they would delay claiming if they could access a lump sum of $\$ 60,000$ at the later age. For instance, in the no work condition, 20 percentage points more respondents would delay claiming, for an increase of $41 \%$ on a base of 49.9 percentage points. In the case where delayed claiming meant more work, 9.4 percentage points more respondents would delay claiming, for an increase of $22 \%$ on a base of 45.6 percentage points.

Table 1

It is interesting that the percent of men willing to delay claiming under the status quo was slightly lower than women, though in the no work condition, more men were willing to delay (49\%) than women (36\%). About the same fraction, 10\%, indicated they would delay if they had to work part time. For those age 50-70 when surveyed, over 39-40\% agreed to delay for a lump sum in the no work condition and 17-29\% would delay if they had to work part time. Interestingly, both the less-educated and those with some college or more would both delay claiming for the Lump Sum without the work requirement, by 34-50\%. But while the better-educated group would still delay with the work requirement, the less educated did not find this appealing. Similar percentage increases - 42-48\% - are observed for Whites and Blacks without the work requirement, while with a work condition, relatively fewer Whites would delay. Nonetheless with a work requirement, for all but the “Other” group, people express substantial willingness to delay claiming for the actuarially fair lump sum. And finally, Table 1 shows that people self-reporting themselves to be in excellent, very good, or good health, are much more likely - $41 \%$ more so - to delay claiming with a lump sum and no work requirement, and 20\% more with the work condition. Interestingly, delayed claiming for people in fair or poor health rises $40 \%$ without the work 
requirement, but falls by $22 \%$ with the work condition. In other words, the additional work requirement was particularly disliked by those in poor health.

\section{Results: Multivariate Analysis}

Next we turn to a multivariate linear probability analysis to investigate which sorts of people would delay claiming under the Lump Sum offer versus the Status Quo. Table 2 provides regression results, first for a stripped-down model that controls for whether the person was willing to delay under the status quo, as well as key socio-demographic controls: male, age, education, While, self-reported health, and the natural log of household income. Second, we extend the set of controls to include indicators for the respondent being married, having an optimistic expectation of own survival probability (compared to an age/sex-specific cohort life table), household wealth, a financial literacy score, a cognition score, the number of living children (as a proxy for a bequest motive), and the respondent's estimated chance of leaving an inheritance. ${ }^{8}$ The sample size in Columns 1 and 2 includes our entire sample, since everyone received the question on willingness to delay for the initially-offered lump sum of $\$ 60,000$. The next two columns focus on the subset of persons who indicated they would be willing to delay for less that this actuarially fair amount, and the final two columns include only those who stipulated they would be willing to delay for more. Panel A of Table 2 reports findings for the no-work condition, while Panel B summarizes outcomes when the part-time work condition is applied.

Table 2

\footnotetext{
8 The cognition score is provided in the RAND 2012 version of the HRS survey, and the financial literacy score is taken from the 2014 HRS core; the latter is the sum of the number of correct answers to the financial literacy questions in the module. Means for all variables appear in the Appendix Table.
} 
One clear finding in Panel A is that those who were most likely to delay claiming under the status quo were also more willing to delay under the Lump Sum condition. The size of the association is substantial: someone willing to delay under the current system would be 23-38 percentage points more likely to delay given the lump sum, holding other things constant. This translates into an increase of 54\%-74\% given the lump sum and no work option. ${ }^{9}$ In Panel B with the work requirement, the changes are slightly smaller, $46-53 \%$, but still substantial. ${ }^{10}$

We also see in Table 2 that men and women do not differ in their willingness to delay without a work condition, while men were somewhat more willing to defer with the work condition. Younger people, under the age of 59 when surveyed, were also slightly more responsive than their older counterparts. We found very few systematic differences by race, education, health, long-life expectations, cognition, or the number of living children, as well as by marital status and wealth. Only for the subset of those requiring a lump sum in excess of $\$ 60,000$ was there a significant positive effect of the financial literacy score; this confirms with other research showing that more financially literate individuals are more likely to understand annuities (Brown et al. 2016a, b).

Table 3 permits us to examine how much people required in terms of the lump sum that would be sufficient to get them to delay claiming. Panel A focuses on responses in the no work requirement condition, and Panel B on the work requirement condition. In each case, the first and second columns include the same set of controls as before. The dependent variable is measured in thousands of dollars, with mean values appearing at the base of the table. ${ }^{11}$

\section{Table 3}

\footnotetext{
9 That is, 54\% (=38/70) and 74\% (=23/31).

10 That is, $46 \%(=16 / 35)$ and $53 \%(=30 / 56)$.

11 The sample for this table omits one respondent who indicated needing \$10 million to delay, as well as anyone with missing values for the status quo question.
} 
Focusing first on Panel A, we note that the average amount needed to delay claiming was about $\$ 60,400$ for the entire sample. Among those needing less than the initially-offered lump sum, the average was only $\$ 53,000$, while it amounted to $\$ 80,100$ among those needing more. By comparison, in Panel B we see that imposing the work condition raises the average amount required by way of a required lump sum. Here the overall average was $\$ 66,700$ for the entire sample, with a mean of $\$ 53,200$ among those willing to take a lump sum less than initially offered, and \$77,400 among those requiring more. This implies that the utility value of the leisure foregone from part-time work until the delayed claiming age of 66 in the second condition is only about $\$ 6,300$ on average, ${ }^{12}$ a relatively low amount compared to average household income of $\$ 67,000$.

Results in Panel A also indicate that those willing to delay under the status quo generally needed a smaller lump sum to delay under the no work condition. For instance, the first two columns show that respondents’ desired lump sums amounted to $\$ 14,000$ (or 35\%) less if they had earlier indicated willingness to delay claiming. People previously stating they were willing to delay for less than $\$ 60,000$ if offered would need only about $\$ 5,300$ to delay. This is striking in that it is less than $10 \%$ of the actuarially fair lump sum value. Respondents indicating they would demand a lump sum over $\$ 60,000$ to delay, in the final two columns, required a lump sum of $\$ 80,000$ on average, and previous indications that they were willing to delay did not alter this requirement. Additionally, the amounts needed did not differ hugely across different types of respondents, by and large. Thus men, younger persons, whites, those in good health, those with more living children, and those planning on leaving an inheritance, were not statistically different from their counterparts. There is a suggestion that those with more education tended to demand a higher lump

\footnotetext{
12 i.e., $\$ 60,400$ versus $\$ 66,700$ on average.
} 
sum, and those with higher income did as well. The effect of cognition scores is uneven across columns.

Similar results obtain in Panel B of Table 3. Generally speaking, younger persons, whites, those in good health, those with more living children, and those planning on leaving an inheritance, were not statistically different from their counterparts. People with higher household income did require higher lump sums, and having a higher cognition score was again uneven across columns and only marginally statistically significant.

\section{Conclusions and Policy Significance}

Our survey using a nationally representative sample of older Americans age 50-70 has demonstrated that many respondents would be willing to delay claiming their Social Security benefits if they were offered a lump sum to do so. This would have a positive effect on their retirement security, in that their Social Security income stream will rise each year of delay, and indeed benefits claimed at age 70 are over $75 \%$ higher than at age 62 . Our survey posed two scenarios to our respondents, one of asked whether they would be willing to receive their delayed Social Security retirement benefit as a lump sum instead of a lifetime benefit stream, without their having to work longer, and the second asked whether respondents would take delayed benefits instead of a lump sum if they had to work longer.

We show that many people would delay claiming if they could access a lifelong benefit plus an actuarially fair lump sum payment, instead of only the higher lifelong benefit as is the case in the current system. For instance, without the work condition, 20 percentage points additional respondents would delay claiming compared to the status quo, and when part time work is required, 9.4 percentage points more respondents would do so. Moreover, many people would be 
willing to delay claiming for much less than an actuarially fair value. We emphasize that people indicate that they would do so voluntarily, and they would be better off than under the current rules. Accordingly, in no sense would this make them worse off in retirement.

This is important for a number of reasons. First, recent evidence indicates that working longer may well be associated with better mental and physical health (Rohwedder and Willis 2009). Second, if subsets of the population would be willing to delay and work longer for a lessthan actuarially fair lump sum, it suggests that the system could save money by providing these lump sums and people would be better off since they would have access to the delayed claiming incentive. Third, from a macroeconomic perspective, longer work lives also offer additional economic resources to help cover the costs of population aging (NRC 2013). Accordingly, methods that would prompt people to voluntarily delay claiming Social Security benefits in exchange for lump sums - and possibly work longer - could benefit society and the older individuals as well. 


\section{References}

Brown, J. R., A. Kapteyn, and O. S. Mitchell. (2016a). "Framing and Claiming: How Information Framing Affects Expected Social Security Claiming Behavior.” Journal of Risk and Insurance. 83(1): 139-162.

Brown, J. R., A. Kapteyn, E. Luttmer, and O. S. Mitchell. (2016b). “Do Consumers Know How to Value Annuities? Complexity as a Barrier to Annuitization.” Journal of the European Economic Association. Forthcoming.

Chai, J., R. Maurer, O. S. Mitchell, and R. Rogalla. (2013). "Exchanging Delayed Social Security Benefits for Lump Sums: Could This Incentivize Longer Work Careers?” NBER Working Paper 19032

Coile, C., P. Diamond, J. Gruber, and A. Jousten. (2002): “Delays in Claiming Social Security Benefits.” Journal of Public Economics. 84(3): 357-385.

Gustman, A. G. and T. L. Steinmeier. (2015). "Effects of Social Security Policies on Benefit Claiming, Retirement and Saving.” Journal of Public Economics. 129: 51-62

Hernæs, E., S. Markussen, J. Piggott, and K. Røed. (2016). "Pension Reform and Labor Supply.” Journal of Public Economics. 142: 39-55.

Hubener, A., R. Maurer, and O. S. Mitchell. (2015) "How Family Status and Social Security Claiming Options Shape Optimal Life Cycle Portfolios.” Review of Financial Studies. 29(1): 937-978.

Horneff, V., R. Maurer, O. S. Mitchell, and R. Rogalla. (2015). “Optimal Life Cycle Portfolio Choice with Variable Annuities Offering Liquidity and Investment Downside Protection.” Insurance: Mathematics and Economics. 63: 91-107.

Lusardi, A., and Mitchell, O.S. (2014). “The Economic Importance of Financial Literacy: Theory and Evidence.” Journal of Economic Literature. 52(1): 5-44

Maurer, R., O.S. Mitchell, R. Rogalla, and T. Schimetschek. (2016). "Will They Take the Money and Work? An Empirical Analysis of People's Willingness to Delay Claiming Social Security Benefits for a Lump Sum.” Journal of Risk and Insurance. Available online November 2016.

National Research Council. (2013). Aging and the Macroeconomy: Long-term Implications of an Older Population. Washington, DC: NRC.

Pew Research Center. (2010). Baby Boomers Retire. http://www.pewresearch.org/dailynumber/baby-boomers-retire/

Rohwedder, S. and R. Willis. (2010). “Mental Retirement.” Journal of Economic Perspectives. 24(1): 119-138.

Social Security Administration. (SSA 2013). Trustees Report. www.ssa.gov.

Shoven, J. B. and S. N. Slavov. (2012). “The Decision to Delay Social Security Benefits: Theory and Evidence.” NBER Working Paper No. 17866.

Shoven, J. B. and S. N. Slavov. (2014). “Does It Pay to Delay Social Security?” Journal of Pension Economics and Finance. 13(2): 121-144. 
Figure 1: Frequencies of Dollar Amounts Needed to Delay Claiming under the Status Quo vs Lump Sum for Delayed Claiming

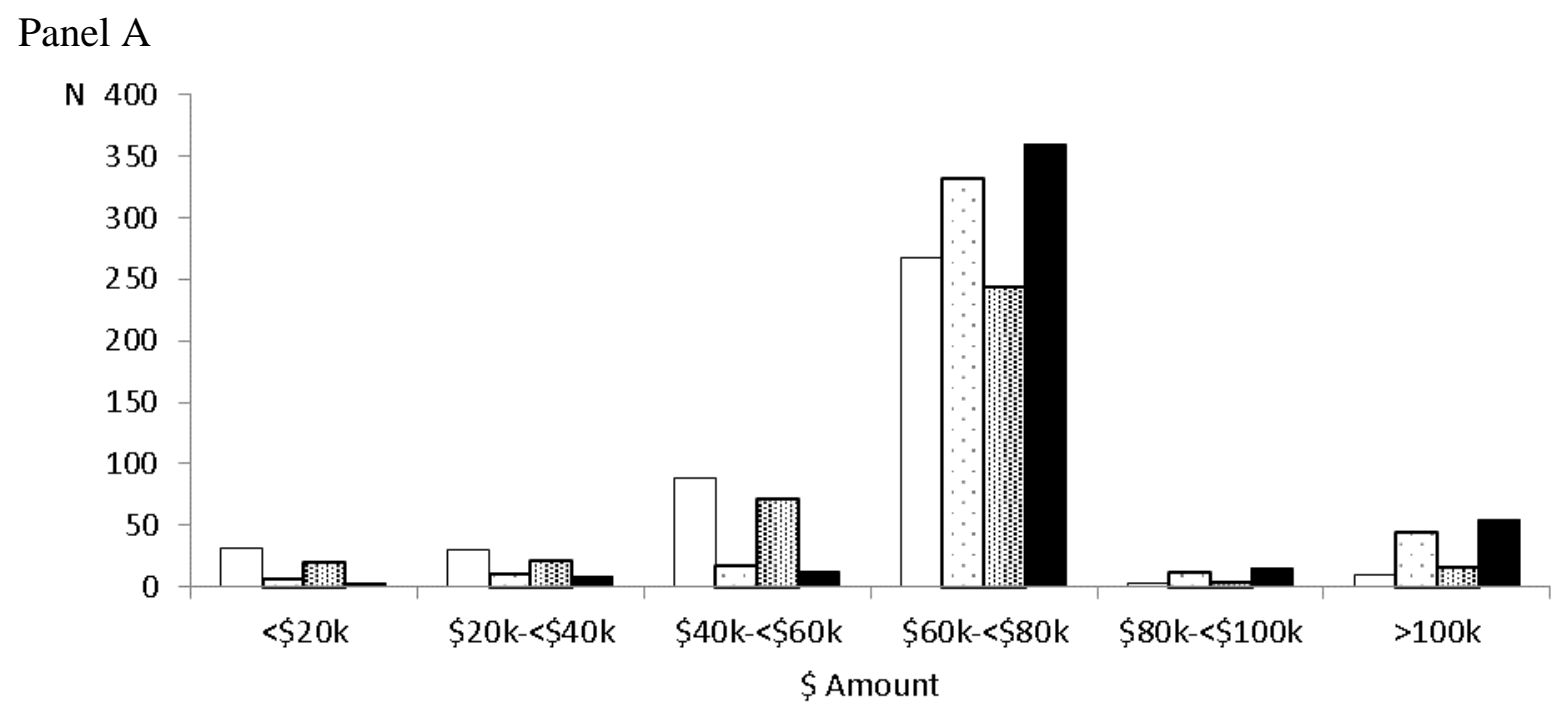

$\square$ No work, will delay $\square$ No work, no delay 图 With work, will delay $\square$ With work, no delay

Panel B:

\begin{tabular}{lr|r}
\cline { 2 - 3 } & No Work & With Work \\
\cline { 2 - 3 } & Will delay & Will delay \\
\hline Mean \$ & 53,711 & 61,406 \\
Std. Dev. \$ & 29,213 & 53,417 \\
\hline N & 430 & 412 \\
\hline Overall N & &
\end{tabular}

Notes: Panel A reports frequencies of dollar amounts for six categories respondents of a HRS 2014 subset indicate they would demand to delay claiming benefits from age 62 to 66 . The two lighter bars in each category indicate the no work condition, while the two darker bars indicate the response when half-time work is required. Panel B reports summary statistics. Source: Authors' calculations. 
Table 1. Frequency (\%) Saying They Would Delay Claiming under the Status Quo vs a Lump Sum of \$60,000, and Differences by Work vs No Work Condition

\begin{tabular}{|c|c|c|c|c|c|c|c|c|}
\hline & \multicolumn{4}{|c|}{ No work } & \multicolumn{4}{|c|}{ With Work } \\
\hline & \multirow[b]{2}{*}{ Status Quo } & \multicolumn{3}{|c|}{ LS-SQ } & \multirow[b]{2}{*}{ Status Quo } & \multicolumn{3}{|c|}{ LS-SQ } \\
\hline & & Lump Sum & Diff & $\%$ change & & Lump Sum & diff & \% change \\
\hline Total & 49.9 & 70.3 & 20.4 & $40.9 \%$ & 45.6 & 55.5 & 9.9 & $21.7 \%$ \\
\hline Men & 46.3 & 69 & 22.7 & $49.0 \%$ & 46 & 55.9 & 9.9 & $21.5 \%$ \\
\hline Women & 52.5 & 71.3 & 18.8 & $35.8 \%$ & 45.3 & 55.2 & 9.9 & $21.9 \%$ \\
\hline 50-59 & 51.5 & 73 & 21.5 & $41.7 \%$ & 46.2 & 59.1 & 12.9 & $27.9 \%$ \\
\hline 60-70 & 48.6 & 67.6 & 19 & $39.1 \%$ & 44.5 & 51.9 & 7.4 & $16.6 \%$ \\
\hline HS or less & 44.5 & 66.9 & 22.4 & $50.3 \%$ & 45 & 44.1 & -0.9 & $-2.0 \%$ \\
\hline Some College+ & 54.6 & 73.3 & 18.7 & $34.2 \%$ & 46 & 56 & 10 & $21.7 \%$ \\
\hline White & 51.3 & 72.8 & 21.5 & $41.9 \%$ & 46.4 & 55.5 & 9.1 & $19.6 \%$ \\
\hline Black & 45.6 & 67.4 & 21.8 & $47.8 \%$ & 39.8 & 56.2 & 16.4 & $41.2 \%$ \\
\hline Other & 51.5 & 63.1 & 11.6 & $22.5 \%$ & 53.5 & 53.1 & -0.4 & $-0.7 \%$ \\
\hline Health E/VG/G & 51.6 & 72.8 & 21.2 & $41.1 \%$ & 47.1 & 56.5 & 9.4 & $20.0 \%$ \\
\hline Health F/P & 45.5 & 63.9 & 18.4 & $40.4 \%$ & 41.8 & 32.6 & -9.2 & $-22.0 \%$ \\
\hline
\end{tabular}

Notes: The table reports relative frequencies (in \% of the overall sample) of respondents indicate they would delay claiming of benefits from age 62 to 66. Left panel represents the no work condition, while the right panel reports when half-time work is required. Source: Authors' calculations. 
Table 2. Linear Probability Regressions on Probability of Delaying under the Lump Sum

\section{A. No Work Condition}

\begin{tabular}{|c|c|c|c|c|c|c|}
\hline \multirow{2}{*}{ WillingtoWaitSQ (V652) } & \multicolumn{2}{|c|}{$\$ 1 \mathrm{k} / \mathrm{mon}+\$ 60 \mathrm{k}$} & \multicolumn{2}{|c|}{$\$ 1 \mathrm{k} / \mathrm{mon}+<\$ 60 \mathrm{k}$} & \multicolumn{2}{|c|}{$\$ 1 \mathrm{k} / \mathrm{mon}+>\$ 60 \mathrm{k}$} \\
\hline & $0.387 * * *$ & $0.380 * * *$ & $0.233 * * *$ & $0.240 * * *$ & $0.310 * * *$ & $0.344 * * *$ \\
\hline & $(0.028)$ & $(0.028)$ & $(0.036)$ & $(0.036)$ & $(0.081)$ & $(0.076)$ \\
\hline \multirow[t]{2}{*}{ Male } & -0.003 & -0.017 & $0.064 *$ & 0.061 & 0.048 & -0.003 \\
\hline & $(0.029)$ & $(0.030)$ & $(0.037)$ & $(0.039)$ & $(0.061)$ & $(0.062)$ \\
\hline \multirow[t]{2}{*}{ Age less than 59} & $0.056 * *$ & $0.065 * *$ & $0.082 * *$ & $0.090 * *$ & $0.106 *$ & 0.097 \\
\hline & $(0.028)$ & $(0.028)$ & $(0.037)$ & $(0.037)$ & $(0.063)$ & $(0.064)$ \\
\hline \multirow[t]{2}{*}{ Some college + } & -0.006 & -0.023 & -0.020 & -0.036 & 0.061 & -0.022 \\
\hline & $(0.029)$ & $(0.032)$ & $(0.037)$ & $(0.041)$ & $(0.064)$ & $(0.071)$ \\
\hline \multirow[t]{2}{*}{ White } & 0.046 & 0.041 & 0.026 & 0.031 & 0.053 & -0.030 \\
\hline & $(0.030)$ & $(0.031)$ & $(0.040)$ & $(0.043)$ & $(0.063)$ & $(0.064)$ \\
\hline \multirow[t]{2}{*}{ Self-reported good health } & 0.050 & 0.027 & -0.020 & -0.027 & 0.058 & -0.009 \\
\hline & $(0.032)$ & $(0.032)$ & $(0.043)$ & $(0.044)$ & $(0.065)$ & $(0.068)$ \\
\hline \multirow[t]{2}{*}{ Ln(HH income) } & $0.014 * *$ & 0.010 & $-0.031 * * *$ & $-0.037 * * *$ & $=0.001$ & -0.011 \\
\hline & $(0.007)$ & $(0.008)$ & $(0.010)$ & $(0.010)$ & $(0.014)$ & $(0.015)$ \\
\hline \multirow[t]{2}{*}{ Married } & & -0.020 & & 0.013 & & 0.102 \\
\hline & & $(0.030)$ & & $(0.040)$ & & $(0.069)$ \\
\hline \multirow[t]{2}{*}{ Optimistic live } & & 0.039 & & 0.037 & & -0.029 \\
\hline & & $(0.031)$ & & $(0.040)$ & & $(0.072)$ \\
\hline \multirow[t]{2}{*}{ Wealth $(\$ 1,000)$} & & 0.000 & & 0.000 & & 0.000 \\
\hline & & $(0.000)$ & & $(0.000)$ & & $(0.000)$ \\
\hline \multirow[t]{2}{*}{ Financial literacy index } & & 0.007 & & 0.025 & & $0.085 * *$ \\
\hline & & $(0.020)$ & & $(0.025)$ & & $(0.042)$ \\
\hline \multirow[t]{2}{*}{ Cognition score } & & 0.005 & & $-0.008 *$ & & -0.004 \\
\hline & & $(0.004)$ & & $(0.005)$ & & $(0.009)$ \\
\hline \multirow[t]{2}{*}{ \# living children } & & $0.019 * * *$ & & 0.006 & & -0.013 \\
\hline & & $(0.007)$ & & $(0.009)$ & & $(0.020)$ \\
\hline \multirow[t]{2}{*}{ Prob. leave inheritance 10k/+ } & & 0.001 & & 0.000 & & $0.002 * *$ \\
\hline & & $(0.000)$ & & $(0.001)$ & & $(0.001)$ \\
\hline \multirow[t]{2}{*}{ Intercept } & $0.275 * * *$ & 0.148 & $0.426 * * *$ & $0.600 * * *$ & 0.197 & $0.349 *$ \\
\hline & $(0.072)$ & $(0.102)$ & $(0.107)$ & $(0.139)$ & $(0.139)$ & $(0.205)$ \\
\hline $\mathrm{N}$ & 889 & 889 & 612 & 612 & 256 & 256 \\
\hline R-squared & 0.203 & 0.222 & 0.085 & 0.102 & 0.090 & 0.181 \\
\hline Mean of dependent variable & 0.703 & 0.703 & 0.306 & 0.306 & 0.414 & 0.414 \\
\hline Std.dev. of dependent variable & 0.457 & 0.457 & 0.461 & 0.461 & 0.494 & 0.494 \\
\hline
\end{tabular}

(cont) 
(cont)

\section{B. With Work Condition}

\begin{tabular}{|c|c|c|c|c|c|c|}
\hline \multirow{2}{*}{$\overline{\text { WillingtoWaitSQ (V652) }}$} & \multicolumn{2}{|c|}{$\$ 1 \mathrm{k} / \mathrm{mon}+\$ 60 \mathrm{k}$} & \multicolumn{2}{|c|}{$\$ 1 \mathrm{k} / \mathrm{mon}+<\$ 60 \mathrm{k}$} & \multicolumn{2}{|c|}{$\$ 1 \mathrm{k} / \mathrm{mon}+>\$ 60 \mathrm{k}$} \\
\hline & $0.302 * * *$ & $0.300 * * *$ & $0.226 * * *$ & $0.228 * * *$ & $0.168 * * *$ & $0.162 * * *$ \\
\hline & $(0.032)$ & $(0.033)$ & $(0.039)$ & $(0.039)$ & $(0.054)$ & $(0.054)$ \\
\hline \multirow[t]{2}{*}{ Male } & 0.025 & 0.022 & $0.103 * *$ & $0.107 * *$ & $0.131 * * *$ & 0.083 \\
\hline & $(0.033)$ & $(0.034)$ & $(0.042)$ & $(0.044)$ & $(0.049)$ & $(0.052)$ \\
\hline \multirow[t]{2}{*}{ Age less than 59} & $0.063 *$ & $0.061 *$ & 0.060 & $0.074 *$ & -0.021 & -0.021 \\
\hline & $(0.033)$ & $(0.033)$ & $(0.042)$ & $(0.043)$ & $(0.050)$ & $(0.050)$ \\
\hline \multirow[t]{2}{*}{ Some college +} & -0.026 & -0.023 & -0.048 & -0.063 & -0.058 & $-0.097 *$ \\
\hline & $(0.035)$ & $(0.038)$ & $(0.042)$ & $(0.048)$ & $(0.052)$ & $(0.057)$ \\
\hline \multirow[t]{2}{*}{ White } & -0.003 & -0.005 & 0.035 & 0.042 & 0.015 & -0.037 \\
\hline & $(0.034)$ & $(0.036)$ & $(0.044)$ & $(0.048)$ & $(0.056)$ & $(0.058)$ \\
\hline \multirow[t]{2}{*}{ Self-reported good health } & 0.028 & 0.021 & -0.050 & -0.076 & 0.009 & -0.028 \\
\hline & $(0.037)$ & $(0.038)$ & $(0.049)$ & $(0.051)$ & $(0.054)$ & $(0.057)$ \\
\hline \multirow[t]{2}{*}{ Ln(HH income) } & -0.004 & -0.007 & $-0.022 * *$ & $-0.027 * *$ & $0.039 * * *$ & $0.031 * *$ \\
\hline & $(0.008)$ & $(0.009)$ & $(0.011)$ & $(0.011)$ & $(0.013)$ & $(0.014)$ \\
\hline \multirow[t]{2}{*}{ Married } & & 0.053 & & -0.016 & & 0.036 \\
\hline & & $(0.036)$ & & $(0.045)$ & & $(0.053)$ \\
\hline \multirow[t]{2}{*}{ Optimistic live } & & $0.062 *$ & & -0.004 & & 0.001 \\
\hline & & $(0.037)$ & & $(0.046)$ & & $(0.055)$ \\
\hline \multirow[t]{2}{*}{ Wealth $(\$ 1,000)$} & & 0.000 & & 0.000 & & 0.000 \\
\hline & & $(0.000)$ & & $(0.000)$ & & $(0.000)$ \\
\hline \multirow[t]{2}{*}{ Financial literacy index } & & -0.011 & & 0.005 & & $0.091 * * *$ \\
\hline & & $(0.023)$ & & $(0.030)$ & & $(0.034)$ \\
\hline \multirow[t]{2}{*}{ Cognition score } & & 0.005 & & 0.002 & & -0.005 \\
\hline & & $(0.005)$ & & $(0.006)$ & & $(0.007)$ \\
\hline \multirow[t]{2}{*}{ \# living children } & & -0.008 & & 0.017 & & 0.014 \\
\hline & & $(0.009)$ & & $(0.012)$ & & $(0.013)$ \\
\hline \multirow[t]{2}{*}{ Prob. leave inheritance $10 \mathrm{k} /+$} & & 0.000 & & 0.000 & & 0.001 \\
\hline & & $(0.000)$ & & $(0.001)$ & & $(0.001)$ \\
\hline \multirow[t]{2}{*}{ Intercept } & $0.398 * * *$ & $0.355 * * *$ & $0.357 * * *$ & $0.312 *$ & -0.146 & -0.077 \\
\hline & $(0.086)$ & $(0.123)$ & $(0.116)$ & $(0.160)$ & $(0.132)$ & $(0.187)$ \\
\hline $\mathrm{N}$ & 860 & 860 & 470 & 470 & 369 & 369 \\
\hline R-squared & 0.101 & 0.115 & 0.086 & 0.113 & 0.081 & 0.122 \\
\hline Mean of dependent variable & 0.555 & 0.555 & 0.299 & 0.299 & 0.346 & 0.346 \\
\hline Std.dev. of dependent variable & 0.497 & 0.497 & 0.458 & 0.458 & 0.476 & 0.476 \\
\hline
\end{tabular}

Notes: ** Significant at 0.05 level, ${ }^{* * *}$ Significant at 0.01 level. All models also include missing value dummies with robust errors clustered on $\mathrm{HH}$

Source: Authors' calculations. 
Table 3: Linear Multivariate Regressions on Dollar Amount (\$000) Needed to Delay: Status Quo vs Lump Sum

\section{A. No Work Condition}

\begin{tabular}{|c|c|c|c|c|c|c|}
\hline & \multicolumn{2}{|c|}{$\$ 1 \mathrm{k} / \mathrm{mon}+\$ 60 \mathrm{k}$} & \multicolumn{2}{|c|}{$\$ 1 \mathrm{k} / \mathrm{mon}+<\$ 60 \mathrm{k}$} & \multicolumn{2}{|c|}{$\$ 1 \mathrm{k} / \mathrm{mon}+>\$ 60 \mathrm{k}$} \\
\hline WillingtoWaitSQ (V652) & $\begin{array}{l}-14.519 * * * \\
(2.632)\end{array}$ & $\begin{array}{l}-14.289 * * * \\
(2.516)\end{array}$ & $\begin{array}{l}-5.320 * * * \\
(1.162)\end{array}$ & $\begin{array}{l}-5.440 * * * \\
(1.147)\end{array}$ & $\begin{array}{r}2.436 \\
(14.473)\end{array}$ & $\begin{array}{r}1.265 \\
(15.110)\end{array}$ \\
\hline Male & $\begin{array}{r}2.175 \\
(2.482)\end{array}$ & $\begin{array}{r}1.521 \\
(2.838)\end{array}$ & $\begin{array}{r}-0.605 \\
(1.193)\end{array}$ & $\begin{array}{r}-0.355 \\
(1.230)\end{array}$ & $\begin{array}{r}8.108 \\
(8.559)\end{array}$ & $\begin{array}{r}0.762 \\
(9.392)\end{array}$ \\
\hline Age less than 59 & $\begin{array}{r}-1.810 \\
(2.377)\end{array}$ & $\begin{array}{r}-1.310 \\
(2.315)\end{array}$ & $\begin{array}{r}-0.808 \\
(1.214)\end{array}$ & $\begin{array}{r}-0.833 \\
(1.229)\end{array}$ & $\begin{array}{r}0.731 \\
(7.936)\end{array}$ & $\begin{array}{r}4.858 \\
(7.815)\end{array}$ \\
\hline Some college + & $\begin{array}{l}7.859 \text { *** } \\
(2.277)\end{array}$ & $\begin{array}{l}4.721 \text { ** } \\
(1.905)\end{array}$ & $\begin{array}{l}2.487 \text { ** } \\
(1.194)\end{array}$ & $\begin{array}{c}2.388 * \\
(1.280)\end{array}$ & $\begin{array}{l}21.097 \text { *** } \\
(7.204)\end{array}$ & $\begin{array}{l}11.203 * \\
(6.744)\end{array}$ \\
\hline White & $\begin{array}{r}2.701 \\
(2.193)\end{array}$ & $\begin{array}{r}-0.279 \\
(2.104)\end{array}$ & $\begin{array}{r}-0.058 \\
(1.366)\end{array}$ & $\begin{array}{r}-1.054 \\
(1.473)\end{array}$ & $\begin{array}{r}9.495 \\
(6.696)\end{array}$ & $\begin{array}{r}3.140 \\
(6.245)\end{array}$ \\
\hline Self-reported good health & $\begin{array}{r}0.774 \\
(1.996)\end{array}$ & $\begin{array}{r}-0.292 \\
(2.106)\end{array}$ & $\begin{array}{r}-0.053 \\
(1.389)\end{array}$ & $\begin{array}{r}-0.136 \\
(1.397)\end{array}$ & $\begin{array}{r}3.374 \\
(5.205)\end{array}$ & $\begin{array}{r}-0.235 \\
(6.901)\end{array}$ \\
\hline Ln(HH income) & $\begin{array}{l}1.100 \text { ** } \\
(0.471)\end{array}$ & $\begin{array}{r}0.726 \\
(0.487)\end{array}$ & $\begin{array}{l}1.595 \text { *** } \\
(0.491)\end{array}$ & $\begin{array}{l}1.593 \text { *** } \\
(0.520)\end{array}$ & $\begin{array}{r}0.856 \\
(0.936)\end{array}$ & $\begin{array}{r}0.042 \\
(0.824)\end{array}$ \\
\hline Married & & $\begin{array}{l}-1.457 \\
(2.469)\end{array}$ & & $\begin{array}{r}-1.014 \\
(1.357)\end{array}$ & & $\begin{array}{l}-1.594 \\
(6.875)\end{array}$ \\
\hline Optimistic live & & $\begin{array}{r}-2.442 \\
(2.687)\end{array}$ & & $\begin{array}{l}-2.703 * \\
(1.444)\end{array}$ & & $\begin{array}{r}3.489 \\
(9.082)\end{array}$ \\
\hline Wealth $(\$ 1,000)$ & & $\begin{array}{r}0.004 \\
-0.005\end{array}$ & & $\begin{array}{r}0.000 \\
(0.001)\end{array}$ & & $\begin{array}{r}0.016 \\
(0.019)\end{array}$ \\
\hline Financial literacy index & & $\begin{array}{r}2.884 \\
(2.557)\end{array}$ & & $\begin{array}{l}-0.622 \\
(0.758)\end{array}$ & & $\begin{array}{l}12.140 \\
(9.187)\end{array}$ \\
\hline Cognition score & & $\begin{array}{r}0.244 \\
(0.350)\end{array}$ & & $\begin{array}{l}0.565 \text { *** } \\
(0.168)\end{array}$ & & $\begin{array}{r}-0.557 \\
(1.220)\end{array}$ \\
\hline \# living children & & $\begin{array}{l}-0.076 \\
(0.411)\end{array}$ & & $\begin{array}{r}0.143 \\
(0.300)\end{array}$ & & $\begin{array}{r}0.717 \\
(1.965)\end{array}$ \\
\hline Prob. leave inheritance $10 \mathrm{k}^{+}$ & & $\begin{array}{r}0.019 \\
(4.550) \\
\end{array}$ & & $\begin{array}{r}-0.006 \\
(7.019) \\
\end{array}$ & & $\begin{array}{r}0.083 \\
(9.607) \\
\end{array}$ \\
\hline Intercept & $\begin{array}{l}49.564 \text { *** } \\
(4.922)\end{array}$ & $\begin{array}{l}47.485 * * * \\
(7.803)\end{array}$ & $\begin{array}{l}38.560 \text { *** } \\
(5.139)\end{array}$ & $\begin{array}{l}28.030 \text { *** } \\
(6.227)\end{array}$ & $\begin{array}{l}48.563 \text { *** } \\
(10.855)\end{array}$ & $\begin{array}{l}56.188 \text { ** } \\
(23.121)\end{array}$ \\
\hline $\mathrm{N}$ & 853 & 853 & 611 & 611 & 242 & 242 \\
\hline R-squared & 0.058 & 0.075 & 0.09 & 0.126 & 0.061 & 0.129 \\
\hline Mean of dependent variable & 60.396 & 60.396 & 52.591 & 52.591 & 80.103 & 80.103 \\
\hline Std.dev. of dependent variable & 37.462 & 37.462 & 14.813 & 14.813 & 62.141 & 62.141 \\
\hline
\end{tabular}

(cont) 
(cont)

B. With Work Condition

\begin{tabular}{|c|c|c|c|c|c|c|}
\hline \multirow[b]{2}{*}{ WillingtoWaitSQ (V652) } & \multicolumn{2}{|c|}{$\$ 1 \mathrm{k} / \mathrm{mon}+\$ 60 \mathrm{k}$} & \multicolumn{2}{|c|}{$\$ 1 \mathrm{k} / \mathrm{mon}+<\$ 60 \mathrm{k}$} & \multicolumn{2}{|c|}{$\$ 1 \mathrm{k} / \mathrm{mon}+>\$ 60 \mathrm{k}$} \\
\hline & $\begin{array}{l}-5.944 \text { ** } \\
(2.696)\end{array}$ & $\begin{array}{l}-5.4711^{* *} \\
(2.665)\end{array}$ & $\begin{array}{l}-5.589 * * * \\
(1.181)\end{array}$ & $\begin{array}{l}-5.654 \text { *** } \\
(1.208)\end{array}$ & $\begin{array}{r}9.897 \\
(7.372)\end{array}$ & $\begin{array}{r}8.737 \\
(7.225)\end{array}$ \\
\hline Male & $\begin{array}{r}0.205 \\
(2.854)\end{array}$ & $\begin{array}{l}-1.197 \\
(3.202)\end{array}$ & $\begin{array}{l}-3.137 * * \\
(1.335)\end{array}$ & $\begin{array}{l}-2.887 * * \\
(1.418)\end{array}$ & $\begin{array}{r}5.077 \\
(5.761)\end{array}$ & $\begin{array}{r}1.289 \\
(6.614)\end{array}$ \\
\hline Age less than 59 & $\begin{array}{r}-0.647 \\
(3.258)\end{array}$ & $\begin{array}{r}0.280 \\
(3.111)\end{array}$ & $\begin{array}{r}-0.969 \\
(1.305)\end{array}$ & $\begin{array}{r}-1.313 \\
(1.299)\end{array}$ & $\begin{array}{r}3.990 \\
(7.606)\end{array}$ & $\begin{array}{r}5.113 \\
(6.925)\end{array}$ \\
\hline Some college + & $\begin{array}{l}5.664 \text { ** } \\
(2.516)\end{array}$ & $\begin{array}{r}3.619 \\
(2.295)\end{array}$ & $\begin{array}{r}1.995 \\
(1.294)\end{array}$ & $\begin{array}{c}2.592 * \\
(1.510)\end{array}$ & $\begin{array}{r}7.914 \\
(4.928)\end{array}$ & $\begin{array}{r}3.685 \\
(4.255)\end{array}$ \\
\hline White & $\begin{array}{l}5.101 * \\
(2.610)\end{array}$ & $\begin{array}{r}2.735 \\
(2.375)\end{array}$ & $\begin{array}{r}-0.704 \\
(1.415)\end{array}$ & $\begin{array}{r}-1.191 \\
(1.521)\end{array}$ & $\begin{array}{l}10.084 * \\
(5.153)\end{array}$ & $\begin{array}{r}5.934 \\
(4.755)\end{array}$ \\
\hline Self-reported good health & $\begin{array}{r}2.765 \\
(1.930)\end{array}$ & $\begin{array}{r}1.449 \\
(1.938)\end{array}$ & $\begin{array}{r}1.046 \\
(1.593)\end{array}$ & $\begin{array}{r}1.383 \\
(1.625)\end{array}$ & $\begin{array}{r}5.539 \\
(3.866)\end{array}$ & $\begin{array}{r}1.810 \\
(3.947)\end{array}$ \\
\hline Ln(HH income) & $\begin{array}{l}1.492 \text { *** } \\
(0.521)\end{array}$ & $\begin{array}{l}1.028 \text { ** } \\
(0.500)\end{array}$ & $\begin{array}{l}1.101 \text { ** } \\
(0.473)\end{array}$ & $\begin{array}{l}1.174^{* *} \\
(0.506)\end{array}$ & $\begin{array}{l}1.974^{* *} \\
(0.993)\end{array}$ & $\begin{array}{r}1.107 \\
(0.800)\end{array}$ \\
\hline Married & & $\begin{array}{r}1.534 \\
(2.194)\end{array}$ & & $\begin{array}{r}-0.344 \\
(1.500)\end{array}$ & & $\begin{array}{r}5.026 \\
(3.828)\end{array}$ \\
\hline Optimistic live & & $\begin{array}{r}-2.120 \\
(2.884)\end{array}$ & & $\begin{array}{r}-0.745 \\
(1.472)\end{array}$ & & $\begin{array}{r}-0.540 \\
(5.990)\end{array}$ \\
\hline Wealth $(\$ 1,000)$ & & $\begin{array}{r}0.007 \\
(0.005)\end{array}$ & & $\begin{array}{r}-0.001 \\
(0.001)\end{array}$ & & $\begin{array}{r}0.009 \\
(0.008)\end{array}$ \\
\hline Financial literacy index & & $\begin{array}{l}3.9377^{* *} \\
(1.817)\end{array}$ & & $\begin{array}{r}-0.507 \\
(0.886)\end{array}$ & & $\begin{array}{r}5.859 \\
(3.954)\end{array}$ \\
\hline Cognition score & & $\begin{array}{l}-0.732 * \\
(0.384)\end{array}$ & & $\begin{array}{r}0.067 \\
(0.223)\end{array}$ & & $\begin{array}{l}-1.036 \text { * } \\
(0.597)\end{array}$ \\
\hline \# living children & & $\begin{array}{r}0.717 \\
(0.459)\end{array}$ & & $\begin{array}{r}0.174 \\
(0.373)\end{array}$ & & $\begin{array}{r}0.798 \\
(0.862)\end{array}$ \\
\hline Prob. leave inheritance $10 \mathrm{k}+$ & & $\begin{array}{r}0.045 \\
(2.668) \\
\end{array}$ & & $\begin{array}{r}0.013 \\
(2.627) \\
\end{array}$ & & $\begin{array}{r}0.073 \\
(6.053) \\
\end{array}$ \\
\hline Intercept & $\begin{array}{l}42.956 * * * \\
(7.249)\end{array}$ & $\begin{array}{l}55.699 * * * \\
(8.191)\end{array}$ & $\begin{array}{l}45.729 * * * \\
(4.827)\end{array}$ & $\begin{array}{l}42.854 \text { *** } \\
(6.355)\end{array}$ & $\begin{array}{c}34.648 \text { ** } \\
(14.800)\end{array}$ & $\begin{array}{l}56.288 \text { *** } \\
(14.604)\end{array}$ \\
\hline $\mathrm{N}$ & 830 & 830 & 468 & 468 & 358 & 358 \\
\hline R-squared & 0.023 & 0.051 & 0.083 & 0.134 & 0.045 & 0.082 \\
\hline Mean of dependent variable & 63.665 & 63.665 & 53.216 & 53.216 & 77.365 & 77.365 \\
\hline Std.dev. of dependent variable & 43.917 & 43.917 & 14.052 & 14.052 & 62.361 & 62.361 \\
\hline
\end{tabular}

Notes: ** Significant at 0.05 level, $* * *$ Significant at 0.01 level. All models also include missing value dummies with robust errors clustered on $\mathrm{HH}$.

Source: Authors’ calculations. 
Appendix: Variable Definitions and Descriptive Statistics

\begin{tabular}{l|rr|rr|} 
& \multicolumn{3}{|c|}{ No work condition } & With work condition \\
\hline & \multicolumn{1}{|c}{ Mean } & Std. Dev. & Mean & Std. Dev. \\
\hline \$ Amount of lumpsum (\$1,000) & 60.40 & 37.46 & 63.66 & 43.92 \\
WillingtoWaitSQ (V652) & 0.50 & 0.50 & 0.50 & 0.50 \\
Male & 0.43 & 0.49 & 0.43 & 0.50 \\
Age less than 59 & 0.47 & 0.50 & 0.48 & 0.50 \\
Some college + & 0.53 & 0.50 & 0.53 & 0.50 \\
White & 0.63 & 0.48 & 0.62 & 0.48 \\
Self-reported good health & 0.72 & 0.45 & 0.72 & 0.45 \\
Ln(HH income) & 10.33 & 2.07 & 10.33 & 2.10 \\
Married & 0.59 & 0.49 & 0.59 & 0.49 \\
Optimistic live & 0.30 & 0.46 & 0.30 & 0.46 \\
Wealth (\$1,000) & 308 & 721 & 309 & 729 \\
Financial literacy index & 1.26 & 0.88 & 1.27 & 0.87 \\
Cognition score & 23.32 & 4.26 & 23.34 & 4.22 \\
\# living children & 2.89 & 1.91 & 2.89 & 1.86 \\
Prob. leave inheritance 10k+ & 59.07 & 39.83 & 59.32 & 39.69 \\
\hline N & 853 & \multicolumn{3}{|c}{830}
\end{tabular}

Source: Authors' calculations using the HRS (see text). 


\section{Online Appendix: HRS 2014 Module 2}

Administered to a random sample of respondents age 70 and younger

V651_INTRO-NOWRK

INTRODUCTION FOR NO WORK REQUIRED

For the sake of these questions, assume that you are currently age 62, and you are single. You are thinking about when to claim your Social Security benefit. If you claim it at age 62, you will receive \$1,000 per month for life. Now imagine you have a choice: either you can receive that \$1,000 monthly benefit from age 62 for life, or you can delay receiving the benefit until age 66. If you delay, assume that you have enough savings to live on without working from age 62 to age 66. Assume that, on average, the government will neither lose nor make money as a result.

\section{V652 NOWRKDEL-ANN}

NO WORK- IF DELAY TO 66 FOR LGR ANNUITY

In exchange for delaying your Social Security benefit until age 66, you will receive a monthly benefit of $\$ 1,330$ dollars per month from age 66 for life. Would you be willing to delay receiving your benefit until age 66?

1. Yes

5. No

8. DK

9. RF

\section{V653_NOWRKDEL-LS}

NO WORK-IF DELAY TO 66 PLUS LUMP SUM

Now suppose that in exchange for delaying your Social Security benefit until age 66, you will then receive a monthly benefit of $\$ 1,000$ per month from age 66 for life, plus a lump sum of $\$ 60,000$ paid at age 66 .

Would you be willing to delay receiving your benefit to age 66?

1. Yes

5. No $\rightarrow$ GO TO V659

8. $\mathrm{DK} \rightarrow \mathrm{GO}$ TO V664

9. $\mathrm{RF} \rightarrow \mathrm{GO}$ TO V664

V654_NOWRK-IFLESSLS

NO WORK- IF SMALLER LUMP SUM IF DELAY TO 66

You indicated that you would be willing to delay your benefit until age 66 in exchange for a lump sum of $\$ 60,000$ paid at age 66 and a monthly benefit of $\$ 1,000$ for life. Would you be willing to take a smaller lump sum with the same monthly benefit?
1. Yes
5. No $\rightarrow$ GO TO V664
8. $\mathrm{DK} \rightarrow \mathrm{GO}$ TO V664
9. $\mathrm{RF} \rightarrow \mathrm{GO}$ TO V664

\section{V655_NOWRK-LESSLSAMT}

NO WRK-SMALLEST LUMP SUM TO DELAY AMOUNT

What is the smallest lump-sum that you would be willing to accept in exchange for delaying your benefit to age 66? [IWER: ENTER '-1' IF R SAYS “would not accept any lump sum”]

Amount (Range -1 to $\$ 99,999,997$ )

DK 99999998

RF 99999999

V656 - V658 Unfolding Sequence

Would it be less than \$, more than \$, or what?

PROCEDURE: 1UP1DOWN 
BREAKPOINTS: $\$ 30,000, \$ 40,000, \$ 50,000$

-------- GO TO V664 -------- 11

V659_NOWRK-IFLRGRLS

NO WRK-IF MORE THAN 60K LUMP SUM TO DELAY

You indicated that you would not be willing to delay your benefit until age 66 in exchange for a lump sum of $\$ 60,000$ paid at age 66 and a monthly benefit of $\$ 1,000$ for life. Would you be willing to delay in exchange for a larger lump sum with the same monthly benefit?

1. Yes

5. No $\rightarrow$ GO TO V664

8. $\mathrm{DK} \rightarrow \mathrm{GO}$ TO V664

9. $\mathrm{RF} \rightarrow \mathrm{GO}$ TO V664

V660_NOWRK-LRGRLSAMT

NO WRK-LRGR THAN 60K LUMP SUM MIN AMOUNT

What is the smallest lump-sum that you would be willing to accept in exchange for delaying your benefit to age 66? [IWER: ENTER '-1' IF R SAYS “would not accept any lump sum”]

$\$ \rightarrow \rightarrow$ GO TO V664

Amount (Range -1 to \$99,999,997)

DK 99999998

RF 99999999

V661 - V663 Unfolding Sequence

Would it be less than $\$$, more than $\$$, or what?

PROCEDURE: 1UP1DOWN

BREAKPOINTS: $\$ 70,000, \$ 80,000, \$ 90,000$

DK 99999998

RF 99999999

ASK EVERYONE

V664_INTRO-WORK

Again, assume you are currently age 62, and you are single. And again you have a similar choice: either you can receive that $\$ 1,000$ monthly benefit for life from Social Security from age 62, or you can delay receiving the benefit until age 66. If you delay, again assume that you have enough savings to live on without working from age 62 to age 66, but you must work at least half time in all four years to get the increased benefit. Like before, assume that, on average, the government will neither lose nor make money as a result.

\section{V665_WRK-DEL66ANN}

WORK_DELAY TO 66_ANNUITY

In exchange for delaying your Social Security benefit and working four additional years until age 66, you will receive a monthly benefit of $\$ 1,330$ per month from age 66 for life.

Would you be willing to work longer and delay receiving the benefits to age 66 ?

1. Yes

5. No

8. DK

9. $\mathrm{RF}$

\section{V666_WORK-DELLS}

WORK-IF DELAY TO 66 PLUS LUMP SUM

Instead, in exchange for delaying your Social Security benefit and working four additional years until age 66, you will receive a monthly benefit of $\$ 1,000$ per month from age 66 for life, plus a lump sum of $\$ 60,000$ paid at age 66 . Would you be willing to work longer and delay receiving the benefits to age 66 ?

1. Yes

5. No $\rightarrow$ GO TO V672

8. $\mathrm{DK} \rightarrow$ GO TO V677 


\section{9. $\mathrm{RF} \rightarrow \mathrm{GO}$ TO V677}

\section{V667_WORK-IFLESSLS}

WORK- IF SMALLER LUMP SUM IF DELAY TO 66

You indicated that you would be willing to delay your benefit and work four additional years until age 66 in exchange for a lump sum of $\$ 60,000$ paid at age 66 and a monthly benefit of $\$ 1,000$ for life. Would you be willing to take a smaller lump sum with the same monthly benefit?

1. Yes

5. No $\rightarrow$ GO TO V677

8. $\mathrm{DK} \rightarrow \mathrm{GO}$ TO V677

9. RF $\rightarrow$ GO TO V677

\section{V668_WRK-LESSLSAMT}

WORK-SMALLEST LUMP SUM TO DELAY AMOUNT

What is the smallest lump-sum that you would be willing to accept in exchange for working and delaying your benefit to age 66 ?

[IWER: ENTER ‘-1’ IF R SAYS “would not accept any lump sum”]

$\$ \rightarrow$ GO TO V677

Amount (Range -1 to \$99,999,997)

DK 99999998

RF 99999999

V669-V671 Unfolding Sequence

Would it be less than \$, more than \$, or what?

PROCEDURE: 1UP1DOWN

BREAKPOINTS: $\$ 30,000, \$ 40,000, \$ 50,000$

GO TO V677

\section{V672_WRK-IFLRGRLS}

WORK-IF MORE THAN 60K LUMP SUM TO DELAY

You indicated that you would not be willing to work and delay your benefit until age 66 in exchange for a lump sum of $\$ 60,000$ paid at age 66 and a monthly benefit of $\$ 1,000$ for life. Would you be willing to work to age 66 and delay in exchange for a larger lump sum with the same monthly benefit?

1. Yes

5. No $\rightarrow$ GO TO V677

8. DK $\rightarrow$ GO TO V677

9. $\mathrm{RF} \rightarrow \mathrm{GO}$ TO V677

\section{V673_WRKDEL-MORE}

WORK-LRGR THAN 60K LUMP SUM MIN AMOUNT

What is the smallest lump-sum that you would be willing to accept in exchange for working and delaying your benefit to age 66 ?

[IWER: ENTER '-1’ IF R SAYS “would not accept any lump sum”]

$\$ \rightarrow$ GO TO V677

Amount (Range -1 to $\$ 99,999,997$ )

DK 99999998

RF 99999999

V674-V676 Unfolding Sequence

Would it be less than \$, more than \$, or what?

PROCEDURE: 1UP1DOWN

BREAKPOINTS: $\$ 70,000, \$ 80,000, \$ 90,000$

\section{ASK EVERYONE:}

V677_HOWCLEAR 
HOW CLEAR WERE QUESTIONS

How clear were the questions we asked -- were they unclear, somewhat clear, mostly clear, or very clear?

1. Unclear

2. Somewhat clear

3. Mostly clear

4. Very clear

8. DK

9. $\mathrm{RF}$ 